裹の昆虫を㖪食しているコサタビタキを確認した。然し之は此境內で繁殖したもので

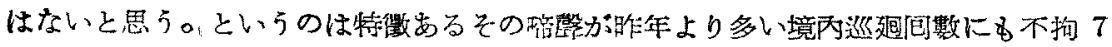
月12日前後まで絕對に耳にすることが出秝なからたからである（時聞は標準封間によ b24時制によつた)。

\title{
Résumé
}

Obsenvations on the nesting habits of Alseonax l. latirostis were mad 3 in the outskirts of Tokyo. The author suggests they probably rear two broods annuàlly.

\section{Further Record of Grus leucogeranus from Japan}

日本産ソデグロヅルに就いて

Dean Amadon

$$
\text { ディーン・アマドン }
$$

Notes on Grus leucogeranus : About a century ago Siebold collected three specimens of the siberian White Crane in Japan and sent them to the Leiden Museum, where they still are(letter from Dr. G. C. A. Junge; July, 1949). These birds were described and one of them figured in the "Fauna Japonica" (1852) by siebold, Temminck and schlegel. The revised Japanese "Hand-List" (1942, p. 175) mentions these specimens as the only ones ever taken in Japan (the actual reference given, for some reason, is to Seebohm's "Birds of the Japanese Empire" [1890], but Seebohm merely repeated the earlier record of siebold).

Recently I noticed a mounted adult of this crane in the collection of birds secured by the American Museum of Natural History from the Verreaux brothers in Paris about 1870. The original label says merely "A Japon" and then lists some bibliographic references to the bird,-in the custom of the day, including the original description by Pallas. Since these references are generally to birds taken in Asia, it seems likely that this specimen actually did come from Japan. This unusual 
日本善ソデグロッ゙ルに就いて・Tマドン

locality would probably not have been placed on the label without reason.

Wild taken museum specimens of Grus leucogeranus are not numerous, although quite a few birds trapped while wintering in northern India have found their way into menageries . (Blaauw, "Monograph Cranes"). Aside from the specimen mentioned above, the three examples of this bird in the American Museum were all obtained from zoos.

The Siberian White Crane is pure white with black primaries. Perhaps because of the scarcity of specimens, some curious errors have fourd their way into the literature. Sharce ("Catalogue of Birds British Museum", volume 23, p. 261) described it as having white primaries and black secondaries; evidently confusing with it an immature of Grus japonensis. Hartert (Vogel paläarktischen Fauna", 3, p. 1820) wrote that it has the primaries and primary coverts white, the remaining plumage snow-white! This was probably only a slio of the pen. 抄 䥻

凡そ1世紀近くも前にかのジーボルトは日本でソデグロッ゙ル Grus leucogeranus の3標品を葛め其等をオランダのライデン博物館に添つたが今年 7 月附 Junge 博士

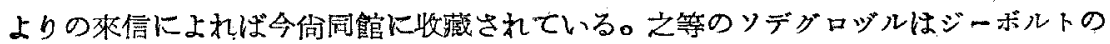
「日本動物誌」中に部裁され且つ其等の内の1狗・[奻鳥] は圆に出してある。「日本 鳥類目錄」第 3 版には之等の標品がこれまで日本で得られた唯一のもので㐫ると彗い てある。ところが最近私は1870年項パリーのVerreaux 兄弟異會からニェーヨーク

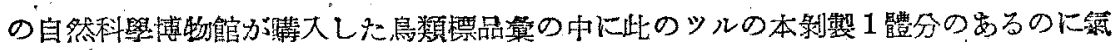
がついた。始めから附いていたラベルには單に “含 Japon”とあるだけだが，此の 普通でない牵地は理由なくしてフベルに記されるようなととはあるまいと想われる。 ソデグロッ゙ルの博物館に藏せられる罴品で野外でとれたものをなるとそ5数多くはな

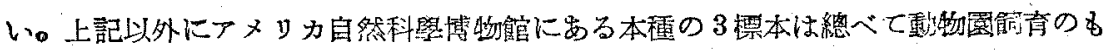
のに由來する。

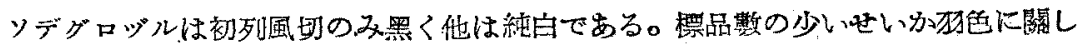

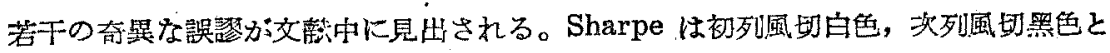
記戴しているが之は明かにタンチョウの炒鳥と混消したるのである。Hartertは初列 風切と初列雨覆が白く他の部分は雪白であると記したがこれはらつかり筆が滑つたの 
であろう。(高島春雄)

【抄譯者註】 ソデグロッ゙ルは近年日本から突を消した鳥である。和䉒フイデンの博 物管に保存される標品が本種の日本にいたことの登左となつているに逼ぎないが，江

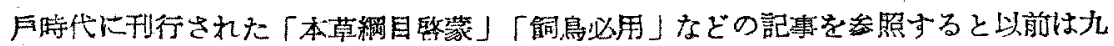
州に相當多數渡來したるのらしい。至く渡らなくなつた原因は不明でる。シロッ゙ル， ソデグロなどとるい5。

\section{The first specimen record of Branta bernicula nigricans from Shikoku}

コクガン四國にて探集さる

Tatsuo Udagawa

字田川龍男

The Black Brant, Branta b. nigricans (Lawrence) was formerly not an uncommon visitor to Japan but it is now exceedingly scarce. Only 12 specimen records since the time of Blakiston are enumerated by Austin(Wildfowl of Japan GHQ. NRS., Report No. 118, p. 20, 1949. Tokyo). The only shikoku record furnished by him is two birds seen near Kochi in mid-January, 1925, which must be the same as the one given by Mr. s. Takashima at Urato, Kochi City.

On December 24, 1947 a single bird was obtained by Mr. T. Hayashi at Sulkumo in Kochi prefecture. According to the collector this brant was grazing alone at the mouth of Matsuda River. It proved to be a male and the specimen is now preserved at. the Government Experimental Forestry Station. This record furnishes the first authentic capture of the Black Brant from Shikoku.

抄

鑗

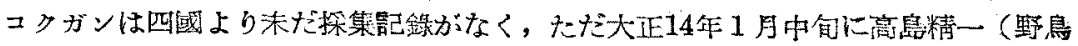

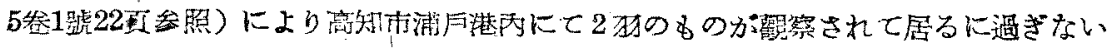

